INSTITUTE OF FORESTRY • BELGRADE

INSTITUT ZA ŠUMARSTVO • BEOGRAD

SUSTAINABLE FORESTRY

COLLECTION 77-78, 2018
ODRŽIVO ŠUMARSTVO

ZBORNIK RADOVA 77-78, 2018

UDK 630*453:595.78(497.11 Novi Pazar)

Original scientific paper

\title{
EXAMINATION OF THE CORRELATION BETWEEN THE DEFOLIATION CAUSED BY NUTRITION OF THE BROWN-TAIL MOTH LARVAE AND THE INCREMENT OF INFESTED SESSILE OAK AND TURKEY OAK TREES
}

\author{
Mara TABAKOVIĆ-TOŠIĆ ${ }^{l}$, Marija MILOSAVLJEVIĆ ${ }^{l}$
}

\begin{abstract}
The paper presents the results of the study research on the effect of the leaf mass reduction caused by the intensive nutrition of an oak defoliating insect - the brown-tail moth Euproctis chrysorrhoea on the annual increment of sessile oak and Turkey oak trees in the coppice forests of the Novi Pazar region (SE Srbijašume, FE Šumarstvo Raška, Novi Pazar Forest Administration, FMU Blizanac-Debelica and FMU NinajaKoznik).
\end{abstract} increment

Key words: the brown-tail moth, defoliation, sessile oak, Turkey oak, annual

ISPITIVANJE KORELACIJE IZMEĐU DEFOLIJACIE IZAZVANE ISHRANOM LARVI ŽUTOTRBE I PRIRASTA INFESTIRANIH STABALA HRASTOVA KITNJAKA I CERA

Izvod: $U$ radu su prikazani rezultati istraživanja uticaja gubitka lisne mase, usled intenzivne ishrane hrastovog defolijatora - žutotrbe Euproctis chrysorrhoea, na godišnje prirašćivanje stabala kitnjaka i cera u izdanačkim šumama Novopazarskog regiona (JP Srbijašume, Šumsko gazdinstvo Šumarstvo Raška, Šumska uprava Novi Pazar, gazdinske jedinice Blizanac-Debelica i Ninaja-Koznik).

Ključne reči: žutotrba, defolijacija, kitnjak, cer, godišnji prirast

${ }^{1}$ Institute of Forestry, Belgrade, Serbia 


\section{INTRODUCTION}

Autochthonous oak forests in southwestern Serbia are exposed to the harmful effects of a series of biotic and abiotic factors, among which an important place is occupied by numerous species of defoliating insects of the Lepidoptera order (gypsy, brown-tail, winter and green oak moth, mottled umber, oak processionary).

The brown-tail moth, Euproctis chrysorrhoea (LINNAEUS, 1758) (Lepidoptera: Erebidae) is native to the Old World where it is found from Algeria in the south to Sweden in the north and from England in the west to the Himalaya Mountains in the east. It is also a common pest of broadleaved forests of central Serbia. The brown-tail moth produces one generation a year. It has four life stages; egg, larva, pupa, and adult. The larval stage lasts for nine months, from August to June. In the autumn, colonies of larvae build winter webs in trees constructed from a single leaf wrapped tightly with large amounts of white silk. A colony consists of 25 to 400 or more larvae.

Although it is extremely polyphagous and feeds on the leaves of most hardwood forest, fruit and ornamental trees (26 genera of forest, fruit, ornamental trees and shrubs belonging to 13 different families), it prefers to consume the leaves of various oak species. It causes the greatest damage in the spring when its larvae feed intensively on the leaves of the host plant and very often cause total defoliation, which leads to decreasing fruiting and a lower growth increment of trees. The continuous repetition of stress, such as defoliation, also reduces the resistance of trees to harmful abiotic and biotic factors and the end result can be the death of attacked trees.

Brown-tail moth occurs periodically in high numbers (outbreaks) on a relatively small area of a few hundred hectares.

Apart from the damage inflicted to forest stands and orchards, the browntail moth belongs to a group of insects that cause severe allergic reactions in humans and animals. Outbreaks of the brown-tail moth in 2014 were recorded in the oak stands of Western Serbia in the forest administrations of Priboj (SE Srbijašume, FE Prijepolje) and Novi Pazar (SE Srbijašume FE Raška), on an area of 1367.19 ha. In some localities of Novi Pazar Forest Administration, coppice forests of sessile oak and Turkey oak were affected by complete defoliation in 2015. Therefore more elaborate studies on its effects on the growth increment of infected trees were conducted in these forests.

\section{MATERIALS AND METHODS}

The intensive research of the possible correlations between the nutrition of the brown-tail moth larvae and the loss in the annual increment of the host tree was conducted in well-preserved oak [Quercus cerris L. and Quercus petraea (MATT.) LIEBL.] coppice forest stands located in the region of Novi Pazar (State Enterprise 'Srbijašume', 'Šumarstvo Raška' Forest Estate, 'Novi Pazar' Forest Administration). The main characteristics of the sample plots where the sampling of brown-tail moth caterpillars and their litters was conducted are presented in Table 1. 
Table 1. The main characteristics of the sample plots.

\begin{tabular}{|c|c|c|c|c|c|}
\hline Plot & Management Unit & Coordinates & $\begin{array}{c}\text { Meters } \\
\text { above } \\
\text { sea level } \\
\text { m a.s.l. }\end{array}$ & $\begin{array}{c}\text { Slope of the } \\
\text { terrain and } \\
\text { aspect }\end{array}$ & $\begin{array}{c}\text { Coeno-ecological } \\
\text { unit of forest stand }\end{array}$ \\
\hline 1 & $\begin{array}{c}\text { Blizanac - Debelica } \\
29 / \mathrm{a}\end{array}$ & $\begin{array}{c}\text { X: } 4783502 \\
\text { Y: } 7454574\end{array}$ & 889 & $\begin{array}{c}6-15^{\circ} \\
\mathrm{E}-\mathrm{NE}\end{array}$ & $\begin{array}{c}\text { Quercetumpetraeae- } \\
\text { cerris }\end{array}$ \\
\hline 2 & $\begin{array}{c}\text { Blizanac - Debelica } \\
30 / \mathrm{a}\end{array}$ & $\begin{array}{c}\text { X: } 4784189 \\
\text { Y: 7 454 691 }\end{array}$ & 863 & $\begin{array}{c}6-15^{\circ} \\
\mathrm{N}-\mathrm{NE}\end{array}$ & $\begin{array}{c}\text { Quercetumpetraeae- } \\
\text { cerris }\end{array}$ \\
\hline 5 & $\begin{array}{c}\text { Ninaja - Koznik } \\
22 / \mathrm{a}\end{array}$ & $\begin{array}{c}\mathrm{X}: 4774038 \\
\mathrm{Y}: 7449982\end{array}$ & 930 & $\begin{array}{c}16-20^{\circ} \\
\mathrm{JE}\end{array}$ & $\begin{array}{c}\text { Quercetumpetraeae- } \\
\text { cerris }\end{array}$ \\
\hline 7 & $\begin{array}{c}\text { Ninaja - Koznik } \\
84 / \mathrm{b}\end{array}$ & $\begin{array}{c}\mathrm{X}: 4774460 \\
\mathrm{Y}: 7489220\end{array}$ & 810 & $\begin{array}{c}21^{\circ} \\
\mathrm{E}\end{array}$ & $\begin{array}{c}\text { Quercetumpetraeae- } \\
\text { cerris }\end{array}$ \\
\hline 8 & $\begin{array}{c}\text { Ninaja-Koznik } \\
85 / \mathrm{b}\end{array}$ & $\begin{array}{c}\mathrm{X}: 4775001 \\
\mathrm{Y}: 7448624\end{array}$ & 920 & $\begin{array}{c}16-20^{\circ} \\
\mathrm{E}\end{array}$ & $\begin{array}{c}\text { Quercetumpetraeae- } \\
\text { cerris }\end{array}$ \\
\hline
\end{tabular}

The population density of the brown-tail moth was determined by using route measurement during the growing season in the period 2014-2016. A detailed quantitative and qualitative analysis of the newly sampled brown-tail moth caterpillar litters was conducted at the laboratory of the Institute of Forestry.

A total of 50 (10 trees x 5 sample plots) randomly selected oak trees of Quercus petraea (Mattuschka) Liebl. and Quercus cerris L. had bore cores taken at breast height using Pressler's borer. The samples were then processed at the laboratory of the Institute of Forestry, Belgrade, using a specialized ADDO Tree-Ring Measuring Instrument.

Statistical analysis of the obtained results was carried out with the help of the software package STATGRAPHICS, version 5.0, and included analysis of variance, calculation of the mean annual increment, and testing of the least significant difference (LSD test).

\section{RESULTS AND DISCUSSION}

In the spring (May and June) of 2014 and 2015 in the selected area in Novi Pazar region (oak and beech coppice forest stands in the management units of Turjak - Vršine, Ninaja - Koznik, Blizanac - Debelica and cadastral municipalities of Slatina, Doljani, Zabrđe, Šavci, Sebečevo, Požega, Pustovlah, Sitniče, Ivanča, Kosuriće, Kovačevo), a great increase in the population size of the brown-tail moth was reported on the area covering 613 ha. 

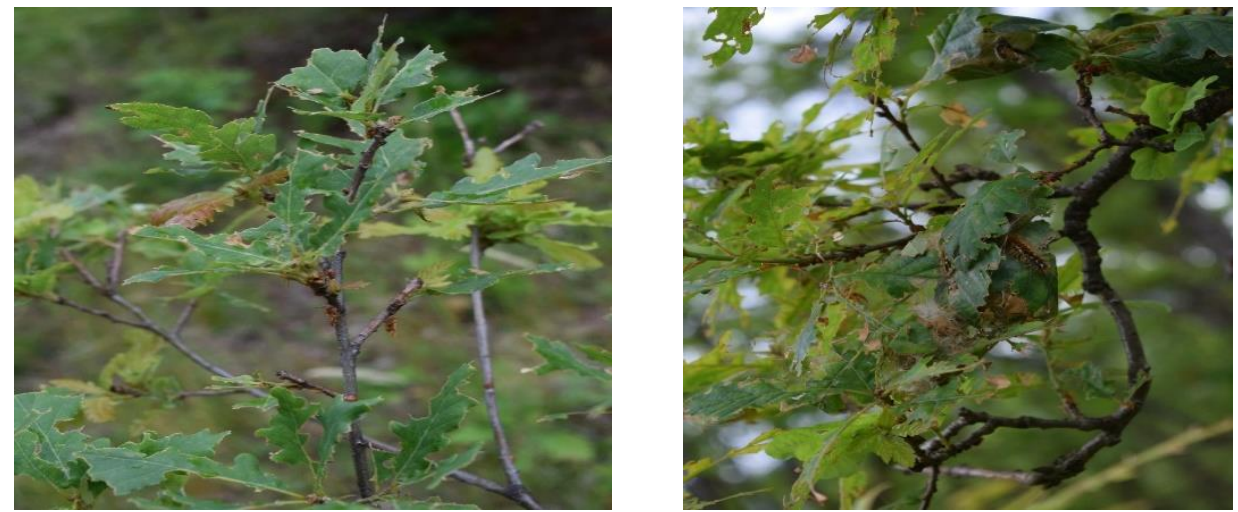

Figure 1. Defoliation of oak and brown-tail moth larvae

The average number of newly formed caterpillar litters in the period 20142015 was 12 , or 17 per tree (minimum 6, maximum 23). The average size of the litter on the established sample plots ranged from 5.1 to $8.9 \mathrm{~cm}$ (length) and from 2.6 to $4.5 \mathrm{~cm}$ (width) (with the maximum length of $19 \mathrm{~cm}$ and width of $8 \mathrm{~cm}$ ).

Generally, defoliation reduces the photosynthetic area and decreases the leaf area per tree (Mattson et al., 2004, Schat \& Blossey 2005, Huttunen et al., 2007). The negative effect of severe and prolonged defoliation on the growth rate or final biomass is usually proportional to the removal of fresh biomass while it could be even positive (Mott et al, 1957; Tunnock \& Rayan, 1985; Belsky, 1986; McNaughton,1986; Long 1988, Alntekirch and Winkel 1990; Eissenstat \& Duncan, 1992; Hoogesteger \& Karlsson, 1992; Oesterheld, 1992; Anten\&Ackerly, 2001; Ferraro \& Oesterheld, 2002; Markkola et al., 2004; Tabaković-Tošić et al., 2011; Araminienè et al., 2015).

The impact of defoliation on tree growth depends on tree species and individual tree resistance (Muzika \& Liebhold 1999). A number of authors have reported that a marked decrease in the tree increment starts when the defoliation exceeds 20-30\% (Schweingruber, 1985; Braker \& Gaggen, 1987; Soderberg, 1991) or more than 40-50\% (Frantz et al., 1986; Petraš, 1993; Araminienè et al., 2015).

There are relatively few research studies of the influence of defoliation caused by the larvae of economically significant outbreak species of Lepidoptera order on the annual increment of the Quercus species. Fratin $(1970,1978)$ states that two years of consecutive canopy defoliation (Quercus robur) reduces the increment by $65 \%$. Partial defoliation of $30 \%$ brings about a reduction of $12 \%$, while $20 \%$ defoliation leads to a $10 \%$ reduction. Mirković \& Mišković (1960) consider that single defoliation generally causes a $40 \%$ decrease in the volume increment of and a $25 \%$ decrease in the diameter increment. Radonjić (1962) came to similar findings in poor-quality oak stands on Kosmaj Mountain in Serbia. After significant defoliation, the increment was reduced by $23 \%$. Androić (1978) states that the complete defoliation reduces the volume increment by $20-50 \%$. 
Table 2.The analysis of the oak diameter increment.

\begin{tabular}{|c|c|c|c|c|c|c|}
\hline \multirow{3}{*}{ Plot } & \multirow{3}{*}{$\begin{array}{c}\text { Bore core } \\
\text { number }\end{array}$} & \multicolumn{5}{|c|}{ Tree ring (annual ring) width in $\mathrm{mm}$} \\
\hline & & & & Year & & \\
\hline & & 2011 & 2012 & 2013 & 2014 & 2015 \\
\hline \multirow{10}{*}{ I } & 1 & 3.70 & 2.64 & 2.84 & 1.22 & 0.68 \\
\hline & 2 & 1.32 & 1.13 & 1.21 & 1.19 & 1.2 \\
\hline & 3 & 0.87 & 1.04 & 1.14 & 0.98 & 1.19 \\
\hline & 4 & 1.24 & 1.34 & 1.54 & 2.25 & 1.79 \\
\hline & 5 & 0.86 & 0.97 & 0.86 & 0.81 & 0.67 \\
\hline & 6 & 1.09 & 0.95 & 1.02 & 1.08 & 0.79 \\
\hline & 7 & 0.73 & 0.58 & 0.79 & 0.93 & 0.42 \\
\hline & 8 & 1.20 & 1.09 & 0.89 & 1.09 & 0.72 \\
\hline & 9 & 1.30 & 1.2 & 1.69 & 1.43 & 0.98 \\
\hline & 10 & 0.74 & 0.84 & 1.06 & 1.02 & 0.79 \\
\hline \multirow{10}{*}{ II } & 11 & 1.62 & 1.57 & 1.28 & 1.03 & 0.94 \\
\hline & 12 & 1.86 & 0.6 & 0.63 & 0.7 & 0.47 \\
\hline & 13 & 0.80 & 0.71 & 0.81 & 1 & 0.82 \\
\hline & 14 & 0.97 & 0.79 & 0.84 & 0.74 & 0.53 \\
\hline & 15 & 0.66 & 0.94 & 0.79 & 0.61 & 0.61 \\
\hline & 16 & 1.37 & 0.76 & 1.44 & $\begin{array}{l}1.08 \\
\end{array}$ & 0.83 \\
\hline & 17 & 1.33 & 1.17 & 1.25 & 0.99 & 0.67 \\
\hline & 18 & 0.74 & 0.66 & $\begin{array}{l}0.7 \\
\end{array}$ & $\begin{array}{l}0.59 \\
\end{array}$ & 0.38 \\
\hline & 19 & 0.95 & 0.9 & 1 & 0.6 & 0.6 \\
\hline & 20 & 0.40 & 0.31 & 0.32 & 0.51 & 0.28 \\
\hline \multirow{10}{*}{ III } & 21 & 0.69 & 0.82 & 0.95 & 0.93 & 0.7 \\
\hline & 22 & 0.91 & 1.51 & 1.4 & 0.9 & 0.69 \\
\hline & 23 & 1.10 & 0.88 & 1.09 & 1.28 & 0.72 \\
\hline & 24 & 1.15 & 1.09 & 0.81 & 0.96 & 0.74 \\
\hline & 25 & 0.54 & 0.65 & 0.67 & 0.75 & 0.4 \\
\hline & 26 & 1.03 & 1.02 & 1.25 & 0.87 & 0.7 \\
\hline & 27 & 0.36 & 0.46 & 0.31 & 0.38 & 0.2 \\
\hline & 28 & 1.60 & 1.36 & 1.55 & 0.93 & 0.35 \\
\hline & 29 & 1.01 & 0.96 & 0.96 & 1.02 & 0.93 \\
\hline & 30 & 0.51 & 0.61 & 0.37 & 0.55 & 0.39 \\
\hline \multirow{10}{*}{ IV } & 31 & 4.09 & 2.74 & 3.61 & 3.69 & 1.49 \\
\hline & 32 & 1.85 & 1.47 & 1.92 & 0.91 & 0.62 \\
\hline & 33 & 1.18 & 1.1 & 1.15 & 1.07 & 0.46 \\
\hline & 34 & 0.99 & 0.87 & 0.73 & 1.6 & 1.05 \\
\hline & 35 & 0.79 & 0.91 & 0.74 & 0.67 & 0.64 \\
\hline & 36 & 1.18 & 1 & 0.68 & 0.67 & 0.33 \\
\hline & 37 & 0.81 & 0.69 & 0.8 & 0.98 & 0.51 \\
\hline & 38 & 0.89 & 0.87 & 0.78 & 0.71 & 0.33 \\
\hline & 39 & 1.03 & 1.1 & 1.5 & 0.77 & 0.42 \\
\hline & 40 & 0.86 & 1.03 & 1.01 & 1.69 & 0.58 \\
\hline \multirow{5}{*}{$\mathrm{V}$} & 41 & 0.61 & 0.93 & 0.99 & 0.59 & 0.2 \\
\hline & 42 & 1.10 & 1.22 & 1.1 & 1.17 & 0.8 \\
\hline & 43 & 1.74 & 1.75 & 1.28 & 1 & 0.59 \\
\hline & 44 & 0.74 & 0.69 & 0.84 & 0.63 & 0.32 \\
\hline & 45 & 0.68 & 0.32 & 0.32 & 0.34 & 0.28 \\
\hline
\end{tabular}




\begin{tabular}{|c|c|c|c|c|c|c|}
\hline \multirow{3}{*}{ Plot } & \multirow{2}{*}{$\begin{array}{c}\text { Bore core } \\
\text { number }\end{array}$} & \multicolumn{5}{|c|}{ Tree ring (annual ring) width in mm } \\
\cline { 2 - 7 } & & $\mathbf{2 0 1 1}$ & $\mathbf{2 0 1 2}$ & $\mathbf{2 0 1 3}$ & $\mathbf{2 0 1 4}$ & $\mathbf{2 0 1 5}$ \\
\cline { 2 - 7 } & 46 & 0.88 & 0.65 & 0.78 & 0.97 & 0.42 \\
\cline { 2 - 7 } & 1.42 & 1.24 & 1.02 & 0.81 & 0.38 \\
\hline 47 & 1.49 & 1.91 & 1.85 & 1.87 & 1.23 \\
\hline 48 & 1.75 & 1.76 & 1.26 & 1.32 & 0.78 \\
\hline & 49 & 1.52 & 1.56 & 1.49 & 1.51 & 0.69 \\
\cline { 2 - 7 } & 50 & 1,17 & 1.07 & 1.11 & 1.03 & 0.67 \\
\hline
\end{tabular}

Table 3. Analysis of Variance.

\begin{tabular}{|c|c|c|c|c|c|}
\hline Source & $\begin{array}{c}\text { Sum of } \\
\text { Squares }\end{array}$ & $\begin{array}{c}\text { Degree of } \\
\text { freedom }\end{array}$ & $\begin{array}{c}\text { Mean } \\
\text { Square }\end{array}$ & F-Ratio & P-Value \\
\hline $\begin{array}{c}\text { Between } \\
\text { groups }\end{array}$ & 7.75704 & 4 & 1.93926 & 6.85 & 0.000 \\
\hline $\begin{array}{c}\text { Within } \\
\text { groups }\end{array}$ & 69.3197 & 245 & 0.282938 & & \\
\hline Total & 77.0767 & 249 & & & \\
\hline
\end{tabular}

Table 4. The least significant difference test for the mean growth ring width.

\begin{tabular}{|c|c|c|c|c|c|}
\hline \multirow{2}{*}{ Year } & \multirow{2}{*}{$\begin{array}{c}\text { Mean growth-ring } \\
\text { width }(\mathbf{m m})\end{array}$} & \multicolumn{4}{|c|}{ Homogeneous group } \\
\cline { 3 - 6 } & & \multicolumn{2}{|c|}{$\mathbf{P}<\mathbf{0 . 0 5}$} & \multicolumn{2}{|c|}{$\mathbf{P}<\mathbf{0 . 0 1}$} \\
\cline { 3 - 6 } & $\mathbf{1}$ & $\mathrm{X}$ & & $\mathrm{X}$ & $\mathbf{2}$ \\
\hline 2015 & 0,67 & & $\mathrm{X}$ & & $\mathrm{X}$ \\
\hline 2014 & 1,03 & & $\mathrm{X}$ & & $\mathrm{X}$ \\
\hline 2013 & 1,07 & $\mathrm{X}$ & & $\mathrm{X}$ \\
\hline 2012 & 1,11 & $\mathrm{X}$ & & $\mathrm{X}$ \\
\hline 2011 & 1,17 & & & & \\
\hline
\end{tabular}

In the period from 2011 to 2014 , the average increment ranged from 1.03 to $1.17 \mathrm{~mm}$, while at the time of defoliation in 2015 , it amounted to $0.67 \mathrm{~mm}$, when its fall could be clearly observed as confirmed by one-way analysis of variance ANOVA (p <0.05, p <0.01) (Table 4).

The obtained results confirmed the positive correlation between the increment and the outbreak of the brown-tail moth, i.e., the defoliation caused by the nutrition of its larvae.

Acknowledgments: The study was partly financed by the Ministry of Science of the Republic of Serbia, the Project 31070 - SUBPROJECT: New technological methods in the integral protection of forests with the focus on the entomopathogenic fungus Entomophaga maimaiga, as the possible solution to the problem of frequent occurrences of the outbreak of gypsy moth in the forest ecosystems of Serbia. 


\section{REFERENCES}

Altenkirch, W., Winkel, W. (1990): Versuche zur Bekämpfung der Lärchenminiermotte (Coleophora laricella Hbn.) mit Hilfe insektenfressen der Vögel. Waldhygiene 18, 233255.

Androić, M. (1978): Effects économiques et écologiques de la defoliation cause par le Bombyx disparate (Porthetria dispar L.) dans les ecosystems forestiers. Plant prot., 143144:155-161.

Anten N.P.R., Ackerly D.D. (2001): Canopy level photosynthetic compensation after defoliation in a tropical understorey palm. Functional Ecology, 15: 252-262.

Araminienè, V., Varnagirytė-Kabašinskienè, I., Stakènas, V. (2015): Defoliation effects on the birch growth: Lithuanian case study. Acta Biol. Univ. Daugavp. 15(1): 9-16.

Belsky A.J. (1986): Does herbivory benefit plants? A review of the evidence. The American Naturalist, 127: 870-892.

Braker O., Gaggen S. (1987): Tree ring Analysis in the Swiss Forest Decline Study. In: Kairiūkštis L., Nilsson S., Straszak A. (eds.): Forest decline and reproduction: Regional and Global Consequences. Laxenburg, Austria. Pp. 124-129.

Eissenstat D., Duncan L.W. (1992): Root growth and carbohydrate responses in bearing citrus trees following partial canopy removal. Tree Physiology, 10: 245-257.

Ferraro D.O., Oesterheld M. (2002): Effect of defoliation on grass growth. A quantitative review. Oikos, 98: 125-133.

Frantz F., Preuchler T., Rohle H. (1986): Vitalitats merkmale und Zuwachsreactionen erkankter Bergwaldbestande in Bayerischen alpenraum. Allgemeine Forstzeitschrift, 41(39): 962-964.

Fratin, A. (1970): Contributii la stabilirea influential defolieror provocate de Lymantria dispar L. asupra productiei arboretelor de Quercinee si la elaborarea masurilor de prevenire a acestor defolieri. Ins. Politechnic, Brasov (Teza de doctorat).

Fratin, A. (1978): Influence des defoliations provoquées par Lymantria dispar sur L'accroissement et la viabilité des peuplements de quercinees. Plant prot. 29,143-144:163168.

Hoogesteger J., Karlsson P.S. (1992): Effects of defoliation on radial stem growth and photosynthesis in the mountain birch (Betula pubescens ssp. tortuosa). Functional Ecology, 6: 317-323.

Huttunen L., Niemelä P., Peltola H., HeiskaS., Rousi M., Kellomäki S. (2007): Is a defoliated silver birch seedling able to overcompensate the growth under changing climate? Environmental and Experimental Botany, 60: 227-238.

Long, G.E. (1988): The larch case bearer in the intermountain northwest. In: Berryman, A.A. (Ed.), Dynamics of Forest Insects and Populations. New York, 1988, pp. 233-242.

Markkola A., Kuikka K., Rautio P., HärmäE., Roitto M., Tuomi J. (2004): Defoliation increases carbon limitation in ectomycorrhizal symbiosis of Betula pubescens. Oecologia, 140: 234-240. 
Mattson W.J., Kuokkanen K., Niemelä P.,Julkunen-Tiitto R., Kellomäki S.,Tahvanainen J. (2004): Elevated $\mathrm{CO}_{2}$ alters birch resistance to Lagomorpha herbivores. Global Change Biology, 10: 14021413.

McNaughton S.J (1986): On plant and herbivores. American Naturalist, 128: 765-770.

Mirković, D., Miščević, V. (1960). Uticaj brsta gubara na prirast hrasta. Zaštita bilja, 60: 3 17.

Mott D.G., Nairn L.D., Cook J.A. (1957): Radial growth in forest trees and effects of insect defoliation. Forest Science, 3 (3): 286-304.

Muzika R.M., Liebhold A.M. (1999): Changes in radial increment of host and non host tree species with gypsy moth defoliation. Canadian Journal of Forest Research, 29:1365-1373.

Oesterheld M. (1992): Effect of defoliation intensity on aboveground and belowground relative growth rates. Oecologia, 92: 313-316.

Petraš R., Nociar V., Pajtik J. (1993): Changes in increment of spruce damaged by air pollution. Lesnictvi - Forestry, 39(3-4):116-122.

Radonjić, S. (1962): Uticaj golobrsta gubara (Limantria dispar) na prirast u šumama društvenog vlasništva na teritoriji Šumske sekcije Mladenovac 1953-1957., Šumarstvo, 1-2: 86-90.

Schat M., Blossey B. (2005): Influence of naturaland simulated leaf beetle herbivory on biomass allocation and plant architecture of purple loosestrife (Lythrum salicaria L.). Environmental Entomology, 34(4): 906-914.

Schweingruber F.H. (1985): Abrupt changes in growth reflected in tree ring sequences as an expression of biotic and abiotic influences. In: Schmid-Haas P. (eds.): Inventory and Monitoring Endangered Forests, proceedings of the IUFRO conference. Birmensdorf, Switzerland. Pp. 291-295.

Soderberg U. (1991): The relation between increment and defoliation of Scots pine and Norway spruce in Sweden. In: Proceedings of IUFRO Workshop on Monitoring Air Pollution Impact on Permanent Sample Plots, Data Processing and Results Interpretation. Prahatice, CSFR. Pp. 119-127.

Tabaković-Tošić, M., Tošić, D., Rajković, S., Golubović-Ćurguz, V., Rakonjac, Lj., (2011): Invasion species Coleophora laricella - one of the main limiting factor of Larix decidua during the forest afforestation and recultivation. African Journal of Agricultural Research, Academic Journals, 6(49): 866 - 872.

Tunnock, S., Rayan, R.B. (1985): Larch Case bearer in Western Larch. U.S. Department of Agriculture - Forest Service, Forest Insect \& Disease, Leaflet 96, 1-7. 


\title{
EXAMINATION OF THE CORRELATION BETWEEN THE DEFOLIATION CAUSED BY NUTRITION OF THE BROWN-TAIL MOTH LARVAE AND THE INCREMENT OF INFESTED TREES OF SESSILE OAK AND TURKEY OAK
}

\author{
Mara TABAKOVIĆ-TOŠIĆ, Marija MILOSAVLJEVIĆ
}

\begin{abstract}
Summary
The defoliation of broadleaved forest tree species is closely related to the outbreak of insects primarily of Lepidoptera species. One of the economically most important species both in Serbia and in other areas of Central and Southeastern Europe is the browntail moth Euproctis chrysorrhoea Linnaeus, 1758 (Lepidotera: Erebidae). At the beginning of the $20^{\text {th }}$ century, it was considered one of the most harmful allochthonous species in North America. Apart from the damage inflicted to forest stands and orchards, the browntail moth belongs to a group of insects that cause severe allergic reactions in humans and animals. It is extremely polyphagous and causes the greatest damage in the spring when its larvae feed intensively on the leaves of the host tree and very often cause total defoliation, which leads to decreasing fruiting and a lower growth increment of trees. The continuous repetition of stress, such as defoliation, also reduces the resistance to harmful abiotic and biotic factors and the end result can be the death of attacked trees.

Outbreaks of the brown-tail moth in 2014 were recorded in the oak stands of Western Serbia in the forest administrations of Priboj (SE Srbijašume, FE Prijepolje) and Novi Pazar (SE Srbijašume FE Raška), on an area of 1367.19 ha. In some localities of Novi Pazar Forest Administration, coppice forests of sessile oak and Turkey oak (Quercion petreae cerris), were affected by complete defoliation in 2015. Therefore more elaborate studies on its effects on the growth of infected trees were conducted in these forests.

A total of 50 randomly selected oak trees of Quercus petraea (Mattuschka) Liebl. and Quercus cerris L., had bore cores taken at breast height using Pressler's borer. The samples were then processed at the laboratory of the Institute of Forestry, Belgrade, using a specialized ADDO Tree-Ring Measuring Instrument. Statistical analysis of the obtained results was carried out with the help of the software package STATGRAPHICS, version 5.0, and included analysis of variance, calculation of the mean annual increment, and testing of the least significant difference (LSD test).

In the period from 2011 to 2014 , the average increment ranged from 1.03 to 1.17 $\mathrm{mm}$, while at the time of defoliation in 2015 , it amounted to $0.67 \mathrm{~mm}$, when its fall could be clearly observed as confirmed by one-way analysis of variance - ANOVA ( $p<0.05, p$ $<0.01)$. The obtained results confirmed the positive correlation between the increment and the outbreak of the brown-tail moth, i.e. the defoliation caused by the nutrition of its larvae.
\end{abstract}




\title{
ISPITIVANJE KORELACIJE IZMEĐU DEFOLIJACIE IZAZVANE ISHRANOM LARVI ŽUTOTRBE I PRIRASTA INFESTIRANIH STABALA HRASTOVA KITNJAKA I CERA
}

\author{
Mara TABAKOVIĆ-TOŠIĆ, Marija MILOSAVLJEVIĆ
}

\begin{abstract}
Summary
Defolijacija lišćarskih šumskih vrsta drveća, usko je povezana sa prenamnoženjem, pre svega insekata iz reda Lepidoptera, a jedan od ekonomski najznačajnijih, kako u Srbiji, tako i u ostalim područjima srednje i jugoistočne Evrope, je žutotrba Euproctis chrysorrhoea Linnaeus, 1758 (Lepidoptera: Erebidae). Početkom 20 veka, smatrana je jednom od najštetnijih alohtonih vrsta u Severnoj Americi. Osim šteta koje nanosi šumskim sastojinama i voćnjacima, žutotrba pripada grupi insekata koji izazivaju jake alergijske reakcije kod ljudi kod životinja. Široko je polifaga, a najveće štete pričinjava u proleće, kada se njene larve intenzivno hrane lišćem domaćina i vrlo često uzrokuju totalnu defolijaciju, koja dovodi do umanjenja plodonošenja i gubitka u prirašćivanju stabala. Uzastopno ponavljanje stresa, poput defolijacije, ima za posledicu i umanjenje otoprnosti na štetne abiotičke i biotičk efaktore, a krajnji rezultat može da bude i potpuno sušenje napadnutih stabala.

Prenamnoženje žutotrbe 2014. godine, zabeleženo je u hrastovim sastojinama zapadne Srbije, u područjima šumskih uprava Priboj (JP Srbijašume, ŠG Prijepolje) i Novi Pazar (JP Srbijašume ŠG Raška), na površini od 1367,19 ha. Na pojedinim lokalitetima Šumske uprave Novi Pazar, u izdanačkim šumama kitnjaka i cera (Quercion petrea ecerris), 2015. godine utvrđen je totalni golobrst, pa su tu obavljena detaljnija istraživanja njegovog uticaja na prirast infestiranih stabala domaćina.

Sa 50 slučajno odabranih stabala hrastova kitnjaka Quercus petraea (Mattuschka) Liebl. i cera Quercus cerris L., uz pomoć Preslerovog svrdla, uzorkovani su izvrtci iz debala (na prsnoj visini), koji su u Institutu za šumarstvo Beograd, laboratorijski obrađeni na specijalizovanom uređaju za merenje godišnjeg prirasta (ADDO). Statistička analiza dobijenih rezultata obavljena je uz pomoć softversko gpaketa STATGRAPHICS, verzija 5.0, a sastojala se od analize varijanse, izračunavanja srednje vrednost igodišnjeg prirasta, kao i testiranja najmanje značajne razlike (LSD test).

Prosečan prirast od 2011. do 2014. godine, kretao se u intervalu od 1,03 do 1,17 $\mathrm{mm}$, dok je u vreme golobrsta (2015.god.) iznosio $0,67 \mathrm{~mm}$, gde se jasno uočava njegov pad, što je potvrđeno i jednofaktorijalnom analizom varijanse - Anova $(\mathrm{p}<0,05)$. Dobijeni rezultati potvrdili su da postojipozitivna korelacija između prirasta i prenamnoženja žutotrbe, odnosno defolijacije izazvane ishranom larvi.
\end{abstract}

